\title{
Demokrácia rózsaszín szemüveg nélkül
}

\author{
KOVÁCS BEÁTA ${ }^{1}$
}

Körösényi András (2019): Manipuláció és demokrácia. Politikaelméleti tanulmányok. Budapest, Gondolat Kiadó, 289 oldal

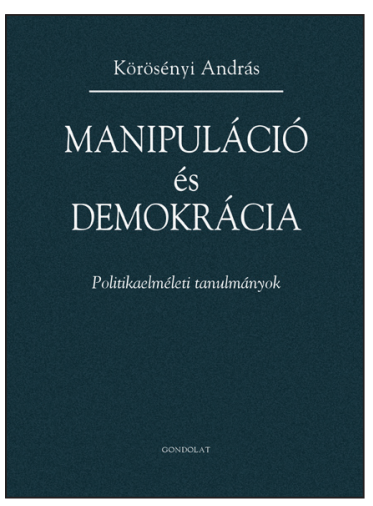

Életem első egyetemi előadásának egyik legemlékezetesebb pillanata az volt, amikor a tanárnő a tudományos megismerés különféle megközelítéseit színes szemüvegekhez hasonlította. Mindnyájan bizonyos szűrőn keresztül tekintünk a felfedezni kívánt jelenségre, ez a szűrő pedig nagymértékben meghatározza, s egyben erősen korlátozza azt, hogy mit is gondolunk az adott (tudományos) problémáról.

Nem véletlen, hogy az előbbi gólya-kori emlék jutott eszembe először Körösényi András Manipuláció és demokrácia címú kötetének olvasása közben. A könyv ugyanis a (liberális) demokrácia ideája és a demokrácia valósága között feszülő ellentétre hívja fel a figyelmet. Vajon lehetséges-e, hogy „rosszul” értelmezzük a demokrácia fogalmát? Gyakran még politikatudósi szerepkörbe helyezkedve is túlságosan erős az a „normatív szűrő”, amelyen keresztül a demokráciához közelítünk. Érdemes lehet tehát legalább egy kis időre félretenni a „rózsaszín”, elvárásokkal és reményekkel teli szemüvegünket, s a realitás talaján mozogva megvizsgálni, hogyan is múködik a valóságban egy demokratikusnak tekintett politikai rendszer. Az itt bemutatandó könyv az előbbiekben nyújthat segítséget.

Körösényi András a magyar politikatudomány egyik legmeghatározóbb alakja, kutatásaiban elsődlegesen a politikai vezetés témáját vizsgálja. A Manipuláció és demokrácia címú tanulmánykötet a 2005-ben megjelent Vezér és demokrácia folytatásának is tekinthető. A könyv tíz demokráciaelméleti tanulmányt tartalmaz, és leginkább a demokrácia és manipuláció viszonyára fókuszál, mindezt pedig realista szemszögből teszi. A szerző három fő tézis köré szervezi a művét. Az első megállapítás szerint a manipuláció a demokrácia szerves részét képezi. A második tétel a politikai vezetők kiemelt szerepére utal, azaz hogy azok valójában nem a népakaratot hajtják végre, hanem sokszor ők maguk azok, akik formálják azt. A végső tézis lénye-

\footnotetext{
${ }^{1}$ Eötvös Loránd Tudományegyetem Politikatudományi Doktori Iskola, e-mail: kovacsb1991@gmail. com
} 


\section{RECENZIÓ}

gében az előbbi kettőnek a következménye, vagyis hogy a demokratikus kormányzás nem „tisztán” demokratikus, hanem voluntarista és autoriter elemekkel tarkított.

A Körösényi által felvázolt modell igen tág mozgásteret biztosít a vezetők számára. Ebben a tág politikai térben pedig a manipuláció, azaz a választói preferenciák alakítása fontos (ha nem a legfontosabb) eszköznek számít a kezükben (első fejezet). A vezetók igazából nem, vagy legalábbis csak igen korlátozott mértékben elszámoltathatók, mivel megválasztásukat követôen nem kötik őket a politikai programok vagy kampányígéretek (második fejezet). A szerző így arra a következtetésre jut, hogy a vezetők kiválasztása biankó csekként múködik, hiszen azoknak nem érdeke, hogy a „népakarat” szerint cselekedjenek, sokkal inkább annak befolyásolására, manipulálására törekszenek. A politika világa kaotikus világ, így a manipuláció eszköz a politikusok kezében arra, hogy látszólagos egyensúlyt teremtsenek a politikában, elviselhetőbbé és kiszámíthatóbbá tegyék a politikai folyamatokat, azaz a milliónyi felkínálkozó lehetőséget befogadható számú politikai üggyé redukálják a választók számára. Az adott (politikai) szituáció ugyanis sosem objektív, szabadon interpretálható, így igazából az válik fontossá, amilyen módon a politikus értelmezi a fennálló helyzetet (harmadik és negyedik fejezet).

A fentebbi folyamatokat felerősíti, hogy a politika piaca a természetes monopóliumok működéséhez hasonlatos. A monopolista verseny hatására ugyanis a belépési küszöb rendkívül magassá válik, azaz senkiből sem lehet egy csapásra politikus. Ez egyrészt morális kockázattal jár, és megteremti a kontraszelekció lehetőségét, másrészt azonban esélyt teremt a hosszabb távú reformok megvalósítására is (ötödik fejezet). Ilyen értelemben a vezetők elsősorban politikai vállalkozóként tűnnek fel, hiszen a siker érdekében nagymértékű kreativitásra, emellett innovatív megoldásokra van szükségük (hatodik fejezet). Ebben a keretrendszerben tehát a vezetők valódi katalizátorként múködnek, hiszen ők azok, akik meghatározzák a politika dinamikáját, és ők azok, akik hajtóerőt biztosítanak a politikai folyamatoknak (hetedik fejezet).

A kötetben szereplő tanulmányok ívét egy kissé megtöri a nyolcadik és kilencedik fejezet (az előbbi Carl Schmitt politikaelméletét tárgyalja, az utóbbi pedig a népszavazások és a modern demokrácia viszonyát értelmezi), mivel azok csak igen nehézkesen helyezhetők el a szerző által felvázolt konceptuális keretben.

Felmerül a kérdés, hogy vajon mennyire univerzálisak a könyvben leírt gondolatok, és mennyiben alkalmazhatók azok a gyakorlatban. Az írások többsége tisztán teoretikus, így nélkülözik az empirikus alátámasztást. A tanulmányok fölött azonban szinte végig ott lebeg az a gondolat, hogy az írót leginkább magyarországi tapasztalatai inspirálták, hiszen a leírtak sokszor rímelnek a magyar politikai helyzetre. Az előbbi kérdésre részben választ kapunk a könyv zárótanulmányában, amely az Orbán-rezsimet tárgyalja a weberi plebiszciter vezérdemokrácia (PVD) keretrendszerében. 


\section{RECENZIÓ}

Az Orbán-rezsim elemzése egyfajta szintézisét nyújtja a kötet mondanivalójának. Lényeges kiindulópont, hogy a szerző nem a „hiányosságai” alapján kívánja leírni a rendszert (miért nem liberális demokrácia), hanem annak tényleges tulajdonságaira koncentrál. Körösényi szerint a PVD egy önálló rezsimtípus, amelyben a képviselet jellege megváltozik, így a karizmatikus vezér válik annak főszereplőjévé. Ezzel párhuzamosan ugyanakkor a rendszer plebiszciter arculattal is rendelkezik, azaz a vezér tevékenysége a nép felhatalmazásán nyugszik. A legitimitás ilyen értelemben demokratikus, hiszen a vezető demokratikus választások során szerezte meg a hatalmat, és a nép kiemelten fontos hivatkozási alapot jelent a számára. Ugyanakkor a PVD tartalmában autoriter jellegű, ami elsősorban a hatalomgyakorlás módjában mutatkozik meg: a politika „kiterjeszkedik” az élet egyéb, elméletben független szféráira is (pl. kultúra), a politikai hatalom pedig elsődlegesen a vezető körül centralizálódik.

Érdekes kérdésnek tűnik, hogy mennyiben igazolódnának be a szerző által felvázolt tézisek, ha azokat magyar kontextuson kívülre helyeznénk. Még ha el is fogadjuk kiindulópontként, hogy a demokratikus kormányzásba szükségszerűen autoriter elemek (is) vegyülnek, akkor sem mindegy, hogy azok milyen mértékben határozzák meg a rendszer működését. Következésképpen az egyes országok politikai rendszerei közötti különbségek feltárása, az empirikus eredmények becsatornázása fontos iránya lehet a jövőbeli kutatásoknak.

Az eddig leírtakból kiderül, hogy a kötet elsődlegesen a politikai vezetőkre és a politikai vezetésre helyezi a hangsúlyt, ugyanakkor szót ejt a „másik oldalról”, a választókról is. Körösényi a Schumpeter által felvázolt realista (vagy inkább peszszimista) antropológiából indul ki a választókat illetően. E megközelítés szerint a hétköznapi állampolgárok nem képesek felelősségteljes döntést hozni a politikai ügyekkel kapcsolatban. Az előbbieket a szerző Schumpeter infantilizmustézisével támasztja alá: „(A) tipikus állampolgár a szellemi teljesítmény alacsonyabb szintjére csúszik, amint a politika mezejére lép. Olyan módon érvel és elemez, amit valódi érdekeinek szféráján belül könnyen infantilisnek tekintene. Újra primitívvé válik. Gondolkodása asszociatív és affektív lesz." (Schumpeter 1943: 262)

A választók tehát a politika terrénumára érkezve irracionálissá válnak: érzelmeik és a pillanatnyi impulzusaik határozzák meg döntéseiket. Az előbbiekből pedig az is következik, hogy irracionalitásuk okán viszonylag egyszerű módon manipulálhatók és befolyásolhatók a politikai vezetők által. Ennek hatására szakadék húzódik a politikusok és a „hétköznapi emberek” között, azaz a választók és a vezetők közötti viszony aszimmetrikus. Az állampolgárok szerepe a kötet által felvázolt keretrendszerben erősen korlátozott, lényegében a vezetők megválasztására redukálódik.

Ezen a ponton szeretnék legalább egy kicsit a „választói oldal” védelmére kelni. Úgy vélem, hogy a racionalitás szerepe sokszor „túlértékelt” a politikai folyamatok tanulmányozása során. Bár már jó ideje meghaladottá vált az a tézis, amely a politikát csupán tisztán racionális érdekek vizsgálata által kívánja leírni, ugyanakkor az érzel- 


\section{RECENZIÓ}

mekre, illetve a politika kevésbé racionális összetevőire sokszor „veszélyes” elemként vagy kiküszöbölendő hibaként tekintünk. Az érzelmek jelenléte valójában természetes része a politikának. A „politikai elme érzelmes elme” (Westen 2007), nem kutat objektív módon a tények, adatok és szakpolitikák után, hogy aztán a legjobban megalapozott döntést hozza meg (Westen 2007). (Politikai) ismereteink megalkotása nem lehet tisztán kognitív folyamat, az érzelmek elvitathatatlan episztemológiai jelentőséggel bírnak, hiszen nélkülözhetetlen szerepük van abban, amilyen módon megismerjük és érzékeljük a világot. Az előbbiekkel egyáltalán nem azt akarom állítani, hogy a racionalitásnak nincs is helye a politikában, inkább amellett szeretnék érvelni, hogy az érzelmek által érzékelt tudás alapvetően nem alacsonyabb rendű a racionalitásnál. Mindemellett a racionalitás csökkenése nem növeli egyértelműen a befolyásolhatóságot sem. Erre jó példa lehet, hogy az összeesküvés-elméletekben ugyanúgy hisznek a társadalmi elit tagjai is, emellett a szociodemográfiai jellemzőknek sincs szignifikáns hatása a konspirációs hiedelmekre (Krekó 2018).

Még ha el is fogadjuk azt az állítást, hogy az állampolgárok leginkább az érzelmeik által vezérelve bolyonganak a politika mezején, felmerül a kérdés, hogy vajon mi a helyzet a politikai vezetőkkel. Nem tévedés talán azt állítani, hogy ők sem tisztán racionális lények. A kötet elsősorban a manipuláció összefüggésében értelmezi a választók és a politikusok viszonyát, így elismeri, hogy a politikai vezetés folyamata egyáltalán nem csak racionalitást kíván. Persze ilyen értelemben a manipuláció leginkább stratégiai forrásként tekint a választók érzelmeire, azaz a vezetők szemszögéből elképzelhető, hogy sokszor éppen emocionálisnak lenni tűnik a leginkább racionális lépésnek. A manipuláció (politikai) magyarázó erejét kár lenne elvitatni: manipulálva vagyunk, s valószínúleg mi magunk is élünk a manipuláció eszközeivel a mindennapokban. Ha azonban a manipuláció valamiféle „alapvető emberi tulajdonság", akkor miért nem foglalkozunk a politikai vezetők manipulálhatóságának és befolyásolhatóságának kérdésével is?

Számomra a kötet legfontosabb tanulsága az, hogy a demokrácia valójában olyan, amilyen mi magunk is vagyunk. A manipuláció „kötött műfaj”, így a politika és a politikai vezetők leginkább azt tükrözik vissza, ami amúgy is „bennünk van”. A választói preferenciákat ugyanis nem lehet patikamérlegen kimérni, így a politikai manipulációt leginkább „körkörös” folyamatként képzelhetjük el, amelyet a vezetők és a választók kölcsönös függése, interakciója jellemez.

Lehet, hogy érdemes lenne először önvizsgálatot tartani, mielőtt visszavennénk a rózsaszín szemüveget? 


\section{RECENZIÓ}

\section{Irodalom}

Krekó P. (2018): Tömegparanoia. Az összeesküvés-elméletek és álhírek szociálpszichológiája. Budapest, Athenaeum Kiadó.

Schumpeter, A. J. (1987 [1943]): Capitalism, socialism and democracy. London, Unwin.

Westen, D. (2007): The political brain. The role of emotion in deciding the fate of the nation. New York, Public Affairs. 